\title{
Perceptions of Coastal Communities on Environmental Based Civic Culture
}

\author{
Mariatul Kiptiah ${ }^{1, *}$ Wahyu Wahyu ${ }^{2}$ \\ 1,2 Pancasila and Civic Education Study Program Faculty of Teacher Training and Education, \\ Lambung Mangkurat University, Banjarmasin, Indonesia \\ *Corresponding author.Email: mariatulkiptiah@ulm.ac.id
}

\begin{abstract}
Coastal communities are a group of people who live together inhabiting coastal areas to form and have a distinctive culture related to their dependence on the use of coastal resources. The understanding of coastal communities in civic culture is that civic culture is an idea related to the moral or ethical identity of citizens towards the environment. Community participation in environment protection is important, studying cultural issues in Indonesia cannot be separated from knowledge of national values. This research is called descriptive qualitative. The sample technique used is purposive sampling.
\end{abstract}

\section{Keywords: Coastal Communities, Civic Culture, Environment.}

\section{INTRODUCTION}

Diverse socio-cultural aspects in the form of a culture that is unique to each region in Indonesia need to be pursued so that it can become a culture that has the ideology of Pancasila as the substance and values contained in civic culture. One of its missions is to build national unity and integrity. This situation is in line with Beiner's thoughts in [1] regarding pluralism, which states that there are 2 (two) theoretical cores that can be distinguished as the basis of possibility. (1) The state is bliged to serve the pluralistic identities of subgroups, not vise verse. (2) There is a requirement that all citizens conform to a large culture, but this culture is nationalcivic, not national-ethnic. The quote implies that citizens who are becoming a wider cultural community need a citizenship culture in the context of this coastal community, the need for civic culture is an idea related to the moral or ethical identity of citizens towards the environment. Community participation for the purpose of preserving the environment is important when studying cultural issues in Indonesia.

It cannot be separated from knowledge of national values. This is also stated by [2]:

Civic Culture must be developed through one of the national cultures which is part of the culture in citizenship. Culture must also be based on citizens' knowledge of the culture that surrounds them and be able to maintain cultural values by forming an identity of a national character by prioritizing the formation of a national identity.

The study of local wisdom must be investigated in order to expand the study of civic culture. The community livelihood system in the swamp environment is an interesting study to learn from, how the values contained includes knowledge, activities and results of environmental protection activities needing to be addressed and improved. Also values to increase civic cultural literacy. Such mentioned, in terms of the existence of Civic Culture can be seen with the habits that are often used by local coastal communities. Based on this, coastal communities as the main actors in the development of environmental areas can do so in the field of cultural arts and community welfare, one of which is the existence of civic culture in the development of environmental protection.

\section{THEORETICAL REVIEW}

In terms of values in the civic culture point of view (citizenship culture). The development of Civic Culture according to [2] is as follows:

Civic culture is "a culture that supports citizenship which contains a set of ideas that can be realized 
collectively in cultural representations for the purpose of forming citizen identity." In the context of civic culture, there are values civic culture, there are marked by the attitude of citizens in the form of: mutual trust, the attitude of the ability to work together, religious belonging, responsibility, solidarity, deliberation, togetherness, and mutual cooperation.

In line with the above opinion regarding civic culture, [3] states that "Civic culture is closely related to national identity. National identity is intended as an identity that is closely related to culture, local wisdom, and customs that exist in every region in Indonesia. Knowledge of civic culture will be useful in the midst of the heterogeneity of Indonesian society as a guide for living together in the national state". [4] explain that "Diverse socio-cultural aspects need to be pursued in order tobecome a national culture with the ideology of Pancasila. This ideology consist of building national unity and integrity as one of its missions. The substance and values contained in Pancasila are what in this thesis is referred to as civic culture, and not an ethnic-core communitarian culture.

The development of values in culture is essentially something that must be done for the development of cultural elements of citizenship. The order of social values that is formed has its own peculiarities so that it forms a different culture in each originating location.

The term Civic culture is inseparable from culture, according to [5], in a cultural system, values as the first level are the most abstract and broad in scope. Cultural systems at this level are ideas or ideas that conceptualize the most valuable things in society. Such conceptions are usually broad and vague, emotionally rooted in the human mind and heart. This level of a cultural system is called a cultural value system.

Culture According to Maclver, is an expression of the soul that is manifested in ways of living and thinking, socializing, art, literature, religion, recreation and entertainment [6]. Discussing culture cannot be separated from the universal cultural elements proposed by anthropologist [7], namely:

1. Language,

2. Knowledge

3. System, Social Organization,

4. Living system and technology equipment,

5. Living system or work livelihood

6. Religious system,

7. Art.

The culture studied by the researcher is about the livelihood system bahuma (farming).

Including other matters relating to the Banjar people as stated by [8] as the following:

What about the livelihood system of the Banjar people? Banjar people are known as water community people because most of them live around the river and use the river as a primary source of their activities, coupled with floating market activities, making their lives more familiar with water, and trading activities are carried out on boats. Most of them live on farming and fishing. Currently there are also those engaged in trade, transportation, mining, development, education and banking.

According to [9], the culture of citizenship (civic culture) is explained to be a necessary step of growth towards a process of nationalization/Indonesianization. The main element of civic culture is civic virtue which includes active citizen involvement, egalitarian or equal relations, mutual trust and tolerance, cooperative life, solidarity, and community spirit. We must explore culture in depth to enrich science. Citizenship education as one of the compulsory subjects from basic education to tertiary education certainly needs to explored, especially in the wetlands area of culture of citizenship. Bahuma is a study of the rural community's livelihood system in farming. This study must be examined further by being made aware of the values of Pancasila for the development through the education sector. Curriculum development must anchor from the existing cultural localities that need to be studied to increase the national educational requirements.

\section{METHODS}

The researcher used a qualitative with descriptive approach as a research method. This is because qualitative can dig deeper into human problems as a research instrument. Interview, observation and documentation methods, as well as analytical techniques, are extensions of human behavior, such as listening, seeing, talking, interacting and asking questions. Qualitative research is useful for obtaining previously unanticipated findings and building new theoretical frameworks.

Thus, the qualitative approach is a naturalistic approach because the situation in the field is what it is and is not manipulated. This research is aimed at developing an environment that can be used to increase public understanding of civicculture based on the culture of coastal communities. According to Fraenkel and Wallen, this study is an empirical study in order to identify and observe the development of people's abilities in managing their environment through habits [10].

Based on its objectives, this research can be categorized as a research that uses a meta-analysis 
approach based on qualitative approach data through indepth interviews. This is in relation to the civic culture within the development area of environmental protection in the Tanah Laut Regency area. What has been done is identifying problems as the first step for strengthening the right foundation to use in creating communities that are capable to increase their capabilities in managing their environment through habits.

\section{RESULTS AND DISCUSSION}

Coastal and marine space as well as resources contained therein are unique, so that human intervention in these areas can result in significant changes. Significant changes are such as difficult to change landscapes, the process of meeting fresh water and sea water which produces several unique ecosystems and others. other. Viewed from the aspect of ownership, coastal andmarine areas, and also the resources contained therein often have an open access nature.

Coastal communities are certainly not only closely related to how much fish they catch every day. It is not necessarily difficult for coastal communities to catch fish because generally they have made the oceans and river areas their main form of livelihood. The problem is that when these conditions are faced with a situation where they must then be able to compete and survive, Tanah Laut Regency, which is one of thirteen cities/districts in the South Kalimantan region, certainly requires more attention. The consideration is that, topographically, Tanah Laut Regency is generally a highland and mountainous area located in the North and East, which is spread out in Pelaihari, Jorong, Batu Ampar, Re-Tambang, and Kintap Districts. It turns out that the southern and western parts are lowland areas including beaches, and swamps. These are located in Kurau and Takisung sub-districts, while Panyipatan is a highland area where the population in general conducts farming.

The identity of the farming community has dignified and increased in value themselves so that they are able to carry out their activities from planting to harvesting. The mental attitude of farmers inagricultural activities explains the value of farming activities. These are tenacity, persistency and responsibility in every farming process so that they are able to harvest optimally. Pancasila in its underlying details has good values that can be associated with their work.

Civic Culture in coastal communities in Tanah Laut Regency has an inner value so that they are able to conduct their living based on the culturalidentity of local wisdom. Their local wisdom along with customs applied by coastal communities related to some people who work as farmers. The identity of the farming community has value in themselves so that they are able to carry out their activities from planting to harvesting. The mental attitude of farmers in agricultural activities explains how farming activities are, they are

tenacious, persistent and responsible in every farming process so that they are able to harvest optimally which is marked by the attitude of citizens in the form of: mutual trust, the attitude of the ability to work together, religious, responsibility, solidarity, deliberation, as in the Banjarese language "Materiandipan dan Ba'arian" which means togetherness and mutual cooperation in completing the planting and harvesting of rice, catching fish and carrying out other community activities. The existence of Civic Culture which is associated with cultural issues in Indonesia cannot be separated from knowledge about national values which are veryclosely related, because Civic culture can be the basis for the formation of citizenship character and enrich the study and value of knowledge in the community about the moralor ethical identity of citizens.

Civic Culture in coastal communities are values from civic culture marked by the attitude of citizens in the form of: mutual trust, the attitude of the ability to work together, religious, responsibility, solidarity, deliberation, togetherness, and mutual cooperation. Based on the description of coastal communities, of course, it is not solely related to the amount of fish they catch every day since it is not difficult for coastal communities to catch fish. This is due generally because they have made the oceans and river areas their main form of livelihood. The problem is that when these conditions are faced with a situation where they must then be able to compete and survive, the profession as farmers and breeders then becomes something of high importance for coastal communities in Tanah Laut district.

Based on the results of interviews with coastal community informants, one of them is a farmer and a trader on the coast in Tanah Laut district, he had expressed the following statement:

"The attitudes of coastal citizens (communities) that are owned through civic culture values are cooperation, responsibility, solidarity, deliberation, togetherness and mutual cooperation. At first we as farmers often planted rice once a year by mutual cooperation or in Banjar language it can be called "bahandipan" with the growth of togetherness in coastal communities. As we await for the harvest season, we discuss to build cooperation in making stalls to sell on the coast as additional income."

The interview above is added and supported by other coastal community informants who work as farmers and has said as follows:

"Civic Culture (citizenship culture) the culture of 
local wisdom has become a custom for our community as a coastal community by doing work together in the sense of working

together so that our work can be completed quickly. Planting rice to harvesting togetherso that the growth of togetherness has become a custom of our local community, which is persistent and tenacious and responsible."

Thus, with the information described by the informants above, it can be seen that the illustration of civic culture in coastal communities in Tanah Laut district had cultivate the cultural identity of local wisdom, as well as customs applied by coastal communities related to people who work as farmers. The identity of the farming community has value in themselves so that they are able to carry out their activities from planting to harvesting process. The mental attitude of farmers in agricultural activities explains how farming activities are, which requires them to be tenacious, persistent and responsible in every farming process so that they are able to harvest optimally. Pancasila in its details has good values that can be associated with their profession.

The results of the interview were added to the informants of coastal community leaders. One of the community leader who lives in a swampy highland area, also has a house on the coast and trades along the coast in Tanah Laut Regency as said the following Firmansyah:

"Civic Culture in coastal communities in Tanah Laut district can be seen from the attitude of citizens who have mutual trust, the attitude of the ability to work together, religious, responsibility and high solidarity so that whatever we do we always hold a careful consideration through deliberate discussion together first, such as harvesting, making fishing boats and welcoming tourist arrivals, there is always a togetherness in the community so that it becomes a cultural value of citizenship that gives birth to the cultural identity of coastal communities."

The development of values in culture is essentially something that must be done for the development of cultural elements of citizenship. The order of social values that is formed has its own peculiarities so that it forms a different culture in each place. Important elements of the culture of a society include the belief system, economic system and kinship system which can be seen in the description of the cultural community that supports citizenship with the aim of forming citizen identity in coastal communities.

Citizenship Culture (Civic Culture) is a cultural identity which is known as "a culture that supports citizenship which contains a set of ideas and ideas that can be realized collectively in cultural representations for the purpose of forming citizen identity. "In the context of civic culture, culture contains values civic culture marked by the attitudes of citizens in the form of: mutual trust, the attitude of the ability to cooperate, religious, responsibility, solidarity, deliberation, togetherness, and mutual cooperation. The illustration of civic culture in coastal communities are integrated in civic culture marked by the attitudes of citizens in the form of: mutual trust, the attitude of the ability to work together, religious, responsibility, solidarity, deliberation, togetherness, and mutual cooperation. From the description of coastal communities, of course, it is not only closely related to how much fish they catch every day. It is not a hard job for coastal communities to catch fish because generally they have made the oceans and riverareas their main form of livelihood. The problem is that when these conditions are faced witha situation where they must then be able to compete and survive, the profession as a farmer then becomes something very important for coastal communities in Tanah Laut district.

Judging from the biophysical aspect of the area, coastal and marine space and the resources contained therein are unique, therefore human intervention in the area can result in significant changes. These changes include landscapes that are difficult to change, the process of meeting fresh water and sea water which produces several unique ecosystems also other applicable changes. When perceived in the form of the ownership aspect, coastal and marine areas, the resources contained therein often have an open access nature.

In line with the above opinion regarding civic culture, [3] explain that "Civic culture is closely related to national identity. National identity is intended as an identity related to culture, local wisdom, and customs that exist in each region in Indonesia. Knowledge of civic culture will be useful in the midst of the heterogeneity of Indonesian society as a guide for living together in the nation and state". [11] explain that "Diverse socio-cultural aspects need to be pursued in order to become a national culture with the ideology of Pancasila. One of its missions is to build national unity and integrity. The substance and values contained in Pancasila are what in this study is referred to as civic culture, not an ethnic-core communitarian culture. The development of values in culture is essentially something that must be done for the development of cultural elements of citizenship. The order of social values that is formed has its own peculiarities so that it forms a distinct culture in every regional place.

Discussing civic culture is inseparable from culture, according to [5] in a cultural system, values are 
seen as the most abstract and broad in a first level scope. Cultural systems at this level are ideas that conceptualize the most valuable things in society. Such conceptions are usually broad and vague, emotionally rooted in the human mind and their hearts. This level of a cultural system is called a cultural value system.

The culture of every nation or society consists of large elements and small elements that are part of a unity that is called a unit. Selo Soemardjan and Soelaeman Soemardi in [6] these several figures have formulated the main elements of culture, for example Melville J. Herskovits proposed four main elements of culture, namely: (1) technological tools, (2) the economic system, (3) family, and (4) political power. Furthermore, Bronislaw Malinowski, who is famous as one of the pioneers of functional theory in Anthropology, mentions the main elements of culture, among others: (1) a system of norms that allows cooperation between community members in an effort to control their natural surroundings, (2) economic organization, (3) educational tools and institutions, and (4) power organization.

Anthropologist C. kluckhohn in his work entitled Universal Categories of Culture has described the universal cultural aspect that can be found in each and every culture [6]. Seven elements of culture are considered as cultural universals, namely:

1) Equipment and supplies for human life (clothing, housing, household appliances, etc.)

2) Livelihoods and economic systems (agriculture, livestock, trade, etc.)

3) Social systems (kinship systems, organization politics, legal system, marriage system)

4) Language (oral and written)

5) Arts (visual arts, sound art, motion art, etc.)

6) Knowledge system

7) Religion (belief system).

Each element of universal culture of course also manifests in the three forms of culture above, namely in the form of a cultural system, a social system, and in the form of elements ofphysical culture. Thus, the economic system has a form in the shape of concepts, plans, policies, customs related to the economy. Moreover, it also has a form in terms of actions and patterned interactions between fishermen, traders and farmers. The order of social values formed has its own peculiarities so that it forms a different culture in each place. Important elements of the culture of a society include the belief system, economic system and kinship system which can be seen in the description of the cultural community that supports citizenship with the aim of forming citizen identity in coastal communities.

[12] explains that culture is a complex whole, which includes knowledge, belief, art, morals, law, customs, and other capabilities acquired by a person as a member of society. [13] defines culture as the whole system of ideas, actions, and human creations in the context of community life, which are made property of humans throughout their learning. The definition according to Koentjaraningrat emphasizes that the culture that exists in human beings has at least three dimensions of existence, namely: (1) a complex of ideas, ideas, values, norms, regulations, human thoughts and so on or is called a cultural system "cultural system", (2) complex patterned activities (actions) of humans in society or called the social system (social system), (3) objects made by humans.

From this definition, it is obtained that the notion of culture is something that will affect the level of knowledge and includes a system of ideas or ideas contained in the human mind. Thus in regards to everyday life, culture itself is abstract. While the embodiment of culture are objects created by humans as cultural beings, in the form of behavior and objects are real, for example patterns of behavior, language, living equipment, social organization, religion, art, and others, which all of which are intended to help humans in carry out social lives.

Therefore, with the information that has been described by the informants above, it can be inferred that the civic culture picture in coastal communities in Tanah Laut district grows the cultural identity of local wisdom. Furthermore, it also builds applicable customs in relation to some people whose profession is to work the field as farmers. The identity of the farming community has a dignified value in themselves so that they are able to carry out their activities from the planting to harvesting process. The mental attitude of farmers in agricultural activities explains how farming activities are, they are tenacious, persistent and responsible in every farming process so that they are able to harvest optimally. Pancasila in its details has the value of goodness that can be associated with work which is marked by the attitude of citizens in the form of: mutual trust, the attitude of the ability to work together, religious, responsibility, solidarity, deliberation, as in the Banjarese language "Badandipan and Ba'arian" which has the meaning of togetherness and mutual cooperation in completing when planting and harvesting rice, catching fish and carrying out other community activities.

The existence of Civic Culture in the Development of Environmental Protection in Coastal Communities based on civic culture is an idea highly relatedto the moral or ethical identity of citizens towards the environment. Community participation in the development of environmental protection becomes 
important, as it is one part of the arts, culture and community welfare.

\section{CONCLUSION}

Civic Culture in coastal communities in Tanah Laut Regency expand growth of cultural identity through local wisdom. It also defines the civic customs applied by coastal communities in relation to those community members who also serve to work as farmers. The identity of the farming community has become dignified and increased in value themselves therefore allowing them to carry out their activities from planting to harvesting. The mental attitude of farmers in agricultural activities explains the value of farming activities. These are tenacity, persistency and responsibility in every farming process so that they are able to obtain the optimum harvest. Pancasila in its details has the value of goodness that can be associated with the communities' work and their way of living. These values are marked by the attitude of citizens in the form of: mutual trust, the attitude of the ability to work together, religious, responsibility, solidarity, deliberation, as in the Banjarese language "Badandipan and Ba'arian" which has the meaning of togetherness and mutual cooperation in completing work when planting and harvesting rice, catching fish and carrying out other community activities.

\section{REFERENCES}

[1] Alrahkman. R, "Development of Indonesian Citizenship Culture Through Citizenship Education in the Pasundan Community (Thesis)," Universitas Pendidikan Indonesia, 2008.

[2] H. Mauludea, Effectiveness of the Application of the Time Token Arends Method in Learning History for Class $X$ Students of Office Administration at SMKN 1 Sambas for the 2009/2010 Academic Year. Yogyakarta: UNY, 2011.

[3] B. P. Mahardika dan S. Aisjah, "Testing Pecking Order Theory and Trade Off Theory on Company Capital Structure (Study on Consumer Goods Companies on the Indonesia Stock Exchange," Sci. J. FEB Students, vol. 2, no. 2, 2014.

[4] M. Benjamin, Conflict Resolution Education: Building a Young Generation Able to Resolve Conflicts Peacefully. Bandung: CV Yasindo Multi Aspects, 2008.

[5] T. Lut, Between Stomach \& Work Ethic in Islamic Perspective. Jakarta: Gema Insani Press, 2001.
[6] S. Soerjono, Sociology An Introduction. Jakarta: Raja Grafindo Persada, 2007.

[7] Koentjaraningrat, Humans and Culture in Indonesia. Jakarta: Djambatan, 2007.

[8] L. et A1, Resource Management Pattern Promotion Workshop Community-Based Forest System Management. Bandung, 1995.

[9] K. Mariatul. dan D. Ruchliyadi, "Implementation of Student Independence Character in Riverside Elementary School Banjarmasin City," J. Citizsh. Educ., vol. 5, no. 1, hal. 57-65, 2020.

[10] J. P. Frankel dan E. Wallen N, How to Design and Evaluate Research in Education. New York: McGraw-Hill Companies, Inc, 2008.

[11] B. Maftuh, "Internalisasi Nilai-Nilai Pancasila dan Nasionalisme Melalui Pendidikan Kewarganegaraan," Educationist, vol. II, no. 2, hal. 134-143, 2008.

[12] B. T. Edward, Wayang, Indonesian Culture and Pancasila. Jakarta: University of Indonesia Publisher, 1998.

[13] Koentjaraningrat, Some Points of Cultural Anthropology. Jakarta: UI Press, 2009. 